\section{$\underset{\substack{\text { hommes } \\ \text { \& migrations }}}{ }$}

\section{Hommes \& migrations}

Revue française de référence sur les dynamiques

migratoires

\section{$1284 \mid 2010$}

Migrations et environnement

\title{
White Material
}

Film français de Claire Denis

\section{André Videau}

\section{(2) OpenEdition \\ 12 Journals}

Édition électronique

URL : http://journals.openedition.org/hommesmigrations/1277

DOI : 10.4000/hommesmigrations. 1277

ISSN : 2262-3353

Éditeur

Musée national de l'histoire de l'immigration

Édition imprimée

Date de publication : 1 mars 2010

Pagination : 201

ISSN : 1142-852X

\section{Référence électronique}

André Videau, « White Material », Hommes \& migrations [En ligne], 1284 | 2010, mis en ligne le 29 mai

2013, consulté le 22 septembre 2020. URL : http://journals.openedition.org/hommesmigrations/1277

; DOI : https://doi.org/10.4000/hommesmigrations.1277

Ce document a été généré automatiquement le 22 septembre 2020.

Tous droits réservés 


\title{
White Material
}

\author{
Film français de Claire Denis
}

\section{André Videau}

1 Un film qui sème le trouble. On est quelque part en Afrique de l'Ouest, dans un paysage et une époque qui brouillent les pistes. Pas du tout dans le Cameroun idyllique d'une enfance coloniale. Celle du Chocolat de l'auteur (1987). Comme si le temps passé avait rendu la contrée anonyme et dangereuse. Vingt ans après, le boy resplendissant ne sème plus le trouble sensuel. Toujours interprété par Isaac de Bankolé, il n'est plus qu'une idole blessée, un boxeur en fuite qui n'a pas su choisir son camp et qui réclame de l'aide.

2 La plantation de café et la maison des colons sont ravagées par les flammes. Marie Vial, la propriétaire exploitante, tente de sauver ce qui peut l'être et lutte avec la dernière énergie pour préserver au moins la dernière récolte. Au point de nier les évidences, de prendre les apparences pour des réalités. In extremis, échappant aux pires sévices, elle rejoindra le dernier carré des irréductibles dans les camions et les hélicoptères "des forces de l'ordre". Comment en est-on arrivé là ?Flash-back sur les derniers jours tragiques d'une décolonisation ratée. Le pays n'est situé précisément ni dans le temps, ni dans l'espace. Les factions se disputent le pouvoir avec des hordes de soldats dépenaillés mais surarmés et éventuellement drogués, disponibles pour le vol, le viol et le racket.

3 Une fois de plus, Claire Denis a choisi l'Afrique, faisant endosser sa passion immodérée par un personnage qui lui convient le mieux (Isabelle Huppert). Dans cet attachement viscéral à une terre, comme dans l'absolu d'un amour contre-nature, on retrouve une proximité avec l'hérö̈ne du Barrage contre le Pacifique de Marguerite Duras, porté à l'écran par Rithy Panh en 2008.

4 Mais il est peut-être temps de passer à autre chose. Abandonner cette terre si chère qui va retourner à la brousse, à la poussière rouge, aux plantes épineuses qui blessent, à la bestialité de ses propres enfants, blancs, noirs, métis, tatoués. Cette terre où les lycées et les pharmacies vont se vider, où Marie aura vu sa famille se disloquer (Michel Subor et Christophe Lambert, ses hommes, conquérants devenus de pathétiques loosers), son 
fils chéri, Manuel, retourner à l'état sauvage, en perte totale d'humanité, de voyou fainéant à fou furieux (Nicolas Duvauchelle encore une fois impressionnant).

5 Il faut tout le talent d'Isabelle Huppert pour convaincre qu'elle ne maitrise plus rien dans cet univers faulknérien, imaginé par la réalisatrice Claire Denis et la scénariste associée Marie N'Diaye (Prix Goncourt 2009 pour Trois femmes puissantes, Gallimard) à partir d'une adaptation du roman de Doris Lessing, Vaincue par la brousse. 